\title{
Penyuluhan Perikanan pada Masa Pandemi COVID-19, Studi Kasus di UPT BRPPUPP Palembang
}

\author{
[Fisheries Extension During the COVID-19 Pandemic, Case Study at BRPPUPP \\ Palembang]
}

\author{
Hendy Dwi Setiawan ${ }^{1}$, Sukma Budi Prasetyati ${ }^{2}$ \\ ${ }^{1}$ Balai Riset Perikanan Perairan Umum dan Penyuluhan Perikanan Palembang \\ ${ }^{2}$ Politeknik Kelautan dan Perikanan Karawang
}

\begin{abstract}
Abstrak
Kinerja penyuluh perikanan terdampak pandemi COVID-19, baik langsung maupun tidak langsung. Dampak tersebut terlihat terutama pada hal-hal yang berhubungan dengan kegiatankegiatan yang bersifat kontak fisik dan pengumpulan massa dalam jumlah banyak. Kondisi pandemi COVID-19 ini masih belum dapat diprediksi hingga kapan berakhirnya. Fungsi penyuluh sebagai katalisator bagi upaya pembangunan perekonomian khususnya pelaku utama perikanan maka penyuluh perikanan harus memiliki strategi yang adaptif dalam pelaksanaan tugasnya selama pandemi COVID-19. Salah satu strategi tersebut adalah pemanfaatan teknologi informasi dan komunikasi yang saat ini berkembang sangat pesat. Tujuan dari penelitian ini adalah menganalisis kondisi dan karakteristik pelaksanaan penyuluhan perikanan dengan pemanfaatan teknologi informasi dan komunikasi secara optimal pada masa pandemi COVID-19. Desain penelitian ini adalah penelitian survei dengan pendekatan deskriptif kualitatif sebab informasi yang terkumpul nantinya dianalisis secara kualitatif. Metode pengumpulan sampel pada penelitian ini dilakukan dengan teknik quota sampling. Narasumber yang menjadi sampel dalam pelaksanaan survei adalah penyuluh perikanan yang berjumlah 140 orang. Penyuluh perikanan masih tetap beraktivitas menjalankan tugas pada masa pandemi dengan protokol kesehatan yang ketat, walaupun dengan intensitas yang relatif menurun sejak awal pandemi hingga sekarang. Karakteristik penyuluh perikanan dalam melaksanakan tugas masih bervariasi; sebagian masih bekerja dengan bertatap muka langsung secara fisik; dan sebagian sudah menerapkan Work from Home (WFH). Data penelitian menunjukkan kondisi penyuluh yang pernah mengalami gejala mirip pasien COVID-19 sebanyak 25,71 persen dan terkonfirmasi reaktif atau positif terpapar infeksi virus COVID-19 sebanyak 24,29 persen. Strategi dan metode penyuluhan perikanan dilakukan secara luring dan daring dengan protokol kesehatan yang ketat dan penggunaan beragam produk teknologi komunikasi.
\end{abstract}

Kata kunci : adaptasi kebiasaan baru; penyuluhan; teknologi informasi dan komunikasi

\section{Abstract}

The performance of fishery extension workers has been affected by the COVID-19 pandemic, either directly or indirectly. The impact is seen especially in matters related to physical contact and gathering large numbers of people. The condition of the COVID-19 pandemic is still not predictable until when it will end. The function of the extension agent as a catalyst for economic development efforts, especially the main actors in fisheries, is that fishery extension workers must have an adaptive strategy in carrying out their duties during the COVID-19 pandemic. One of these strategies is the use of information and communication technology, which is currently growing rapidly. This study aimed to analyze the conditions and characteristics of the implementation of fishery counseling by optimally utilizing information and communication technology during the COVID-19 pandemic. This research design is survey research with a qualitative descriptive approach because the information collected will be analyzed qualitatively. The quota sampling technique carried out the sample collection method in this study. The 
resource persons who were sampled in the survey were fishery instructors, totaling 140 people. Fishery instructors are still active in carrying out their duties during the pandemic with strict health protocols, although with a relatively decreased intensity since the beginning of the pandemic until now. The characteristics of fishery instructors in carrying out their duties are still varied; some still work face-to-face physically, and some have implemented Work from Home (WFH). Research data shows the condition of extension workers who have experienced symptoms similar to COVID-19 patients as much as 25.71 percent and confirmed reactive or positively exposed to COVID-19 virus infection as much as 24.29 percent. Fisheries extension strategies and methods are carried out offline and online with strict health protocols and various communication technology products.

Keywords: extension; information and communication technology; new normal

Penulis Korespondensi

Hendy Dwi Setiawan | hendyds@gmail.com

\section{PENDAHULUAN}

COVID-19 diresmikan oleh Organisasi Kesehatan Dunia (World Health Organization) menjadi pandemi global bertepatan pada 11 Maret 2020. Sutarna et al. (2021) menyebutkan bahwa coronavirus ialah keluarga besar virus yang menimbulkan penyakit pada manusia serta hewan. Pada manusia umumnya menimbulkan penyakit peradangan saluran respirasi, mulai flu biasa sampai penyakit yang lebih parah semacam Middle East Respiratory Syndrome (MERS) serta Sindrom Respirasi Kronis Berat ataupun Severe Acute Respiratory Syndrome (SARS). Coronavirus tipe baru yang ditemui pada manusia semenjak peristiwa luar biasa timbul di Wuhan Tiongkok, pada Bulan Desember 2019, setelah itu diberi nama Severe Acute Respiratory Syndrome Coronavirus 2 (SARS-COV2), serta menimbulkan penyakit Coronavirus Disease2019 (COVID-19).
Kinerja penyuluh Perikanan terdampak pelaksanaannya pada masa pandemi COVID-19 ini, baik secara langsung maupun tidak langsung, terutama pada hal-hal yang berhubungan dengan kegiatan-kegiatan yang bersifat kontak fisik dan pengumpulan massa dalam jumlah banyak. Senada yang diungkapkan oleh Suadnya, Hadi, dan Paramita (2021), metode komunikasi penyuluh dengan sasaran penyuluhan perlu dipilih dan disesuaikan serta target kinerja penyuluh pun terdampak pencapaiannya. Kendala ini akan sangat terasa bagi penyuluh perikanan yang berada di zona merah pandemi COVID-19 dan daerah yang sedang menerapkan Pemberlakuan Pembatasan Kegiatan Masyarakat (PPKM) darurat. Penyuluhan perikanan dalam Peraturan Menteri Kelautan dan Perikanan Nomor 38 tahun 2013 adalah proses pembelajaran bagi pelaku utama serta pelaku usaha agar mereka mau 
dan mampu menolong dan mengorganisasikan dirinya dalam mengakses informasi pasar, teknologi, permodalan, dan sumber daya lainnya sebagai upaya untuk meningkatkan produktivitas, efisiensi usaha, pendapatan, dan kesejahteraannya, serta meningkatkan kesadaran dalam pelestarian fungsi lingkungan hidup. Penyuluh bukan hanya bertugas untuk mendampingi sasaran pelaku utama usaha perikanan tetapi juga menyosialisasikan kepada masyarakat bagaimana cara hidup yang sehat pada pandemi COVID-19 (Choeronawati dan Rochman 2021). Kondisi pandemi COVID-19 ini masih belum dapat diprediksi hingga kapan berakhirnya. Fungsi penyuluh sebagai katalisator bagi upaya pembangunan perekonomian khususnya pelaku utama perikanan maka penyuluh perikanan harus memiliki strategi yang adaptif dalam pelaksanaan tugasnya selama pandemi COVID-19. Strategi tersebut antara lain pemanfaatan teknologi informasi dan komunikasi yang saat ini berkembang sangat pesat. Pengenalan aplikasi media sosial dan situs website menjadi suatu keharusan sebagai media baru yang harus digunakan oleh penyuluh, petani, lembaga pemerintah dan lembaga non-pemerintah untuk menyebarluaskan dan bertukar informasi pertanian (Wibowo 2020). Berbagai fitur aplikasi pesan instan (messenger), video call, video call group, video conference, video sharing channel, podcast, formulir daring (online form) dan platform media sosial lainnya dapat menjadi media pelaksanaan kegiatan penyuluhan perikanan pada masa pandemi COVID-19. Hal senada diungkapkan oleh Prayoga (2017) bahwa sarana teknologi informasi seperti sosial media, video conference dan lain sebagainya kemudian memberikan peluang baru untuk memperlancar kegiatan pertanian.

Adapun tujuan dari penelitian ini adalah menganalisis kondisi dan karakteristik pelaksanaan penyuluhan perikanan dengan pemanfaatan teknologi informasi dan komunikasi secara optimal pada masa pandemi COVID-19.

\section{BAHAN DAN METODE}

Penelitian ini dilakukan pada Bulan Juni-Juli 2021. Penelitian ini didesain sebagai penelitian survei dengan pendekatan deskriptif kualitatif sebab informasi yang terkumpul nantinya hendak dianalisis secara kualitatif. Rustanto (2015) menyatakan bahwa penelitian survei merupakan riset yang dilakukan pada populasi besar ataupun kecil, namun informasi yang dipelajari merupakan informasi dari ilustrasi yang diambil dari populasi tersebut, sehingga ditemui kejadian- kejadian relatif, distribusi serta hubungan-hubungan antar variabel sosiologis ataupun psikologis. Penelitian 
kualitatif memiliki tujuan buat memberikan cerminan tentang sesuatu masyarakat ataupun sesuatu kelompok orang tertentu ataupun cerminan tentang sesuatu indikasi ataupun ikatan antar fenomena.

Dalam penelitian kualitatif dengan memakai tata cara deskriptif, Sugiyono (2009) dalam Rustanto (2015) menyatakan bahwa metode penelitian kualitatif adalah metode penelitian yang digunakan untuk meneliti pada kondisi yang alamiah, di mana peneliti adalah sebagai instrumen kunci, teknik pengumpulan data dilakukan secara triangulasi (gabungan), analisis data bersifat induktif dan hasil penelitian kualitatif lebih menekankan makna daripada generalisasi.

Model penelitian kualitatif ini, jika dilihat dari tujuan yang ingin dicapai, maka termasuk ke dalam model penelitian tindakan. Reason dan Bradbury (1997) dalam Rustanto (2015) menyebutkan bahwa penelitian tindakan merupakan proses partisipatoris dan demokratis yang memadukan tindakan dengan refleksi, teori dengan praktek yang menyertakan pihak lain untuk menemukan solusi praktis terhadap persoalan-persoalan yang menyesakkan dan dan lebih umum lagi demi pengembangan individuindividu bersama komunitasnya.

Metode pengumpulan sampel pada penelitian ini dilakukan dengan teknik sampling kuota (quota sampling). Mardikanto (2011) menjelaskan bahwa quota sampling sebenarnya lebih merujuk pada jumlah sampel yang akan diambil, yaitu apakah dengan menetapkan jumlah (quota) tertentu ataukah secara proporsional, tergantung besar atau kecilnya sub-populasi atau kelompok/kelas/lapisan yang akan diwakili. Panduan yang relatif dapat dipertanggungjawabkan secara ilmiah, di antaranya tergantung sifat populasinya; semakin besar jumlah sampel yang diambil, akan semakin baik. Tetapi kalau bersifat full homogen, dapat diambil dalam jumlah kecil atau bahkan hanya diambil 1 (satu) sampel saja.

Instrumen penelitian berupa kuesioner daring diisi oleh para responden; para penyuluh perikanan melalui Google Form yang disebarluaskan melalui grup Whatsapp komunitas penyuluh perikanan di wilayah sumatera bagian selatan yang tergabung ke dalam satu satuan administrasi pangkal (satminkal) Unit Pelaksana Teknis Balai Riset Perikanan Perairan Umum dan Penyuluhan Perikanan Palembang (UPT BRPPUPP Palembang). Responden yang menjadi sampel adalah 140 orang penyuluh perikanan dari total jumlah penyuluh perikanan keseluruhan sejumlah 498 orang. 
Tabel 1. Karakteristik Kondisi dan Faktor-Faktor yang Mempengaruhi Tingkat Mobilitas Penyuluh Perikanan pada Masa Pandemi COVID-19

\begin{tabular}{|c|c|c|c|}
\hline \multirow[b]{2}{*}{ Parameter } & \multirow[b]{2}{*}{ Kategori } & \multicolumn{2}{|c|}{ Responden } \\
\hline & & Jumlah & $\begin{array}{c}\text { Persentase } \\
(\%)\end{array}$ \\
\hline \multirow{5}{*}{$\begin{array}{l}\text { Jarak tempat tinggal dan tempat } \\
\text { bekerja }\end{array}$} & Kurang dari $30 \mathrm{Km}$ & 86 & 61,43 \\
\hline & $31-50 \mathrm{Km}$ & 33 & 23,57 \\
\hline & $51-100 \mathrm{Km}$ & 11 & 7,86 \\
\hline & $100-200 \mathrm{Km}$ & 6 & 4,29 \\
\hline & Lebih dari $200 \mathrm{Km}$ & 4 & 2,86 \\
\hline \multirow{3}{*}{$\begin{array}{l}\text { Lokasi tempat tinggal dan tempat } \\
\text { bekerja }\end{array}$} & Satu Kabupaten/Kota & 113 & 80,71 \\
\hline & $\begin{array}{l}\text { Beda Kabupaten/Kota } \\
\text { tapi masih Satu } \\
\text { Provinsi }\end{array}$ & 25 & 17,86 \\
\hline & $\begin{array}{l}\text { Beda Kabupaten/Kota, } \\
\text { Beda Provinsi }\end{array}$ & 2 & 1,43 \\
\hline \multirow{3}{*}{$\begin{array}{l}\text { Kendaraan yang digunakan untuk } \\
\text { berangkat kerja }\end{array}$} & Kendaraan Pribadi & 118 & 84,29 \\
\hline & Kendaraan Umum & 4 & 2,86 \\
\hline & $\begin{array}{l}\text { Kombinasi Kendaraan } \\
\text { Umum dan Pribadi }\end{array}$ & 18 & 12,86 \\
\hline \multirow{6}{*}{$\begin{array}{l}\text { Frekuensi bekerja bertatap muka } \\
\text { langsung dengan sasaran penyuluhan } \\
\text { perseorangan pada masa pandemi } \\
\text { COVID-19 }\end{array}$} & 1 kali seminggu & 15 & 10,71 \\
\hline & 2 kali seminggu & 29 & 20,71 \\
\hline & 3 kali seminggu & 40 & 28,57 \\
\hline & 4 kali seminggu & 23 & 16,43 \\
\hline & 5 kali seminggu & 10 & 7,14 \\
\hline & $\begin{array}{l}\text { Lebih dari } 5 \text { kali } \\
\text { seminggu }\end{array}$ & 23 & 16,43 \\
\hline \multirow{6}{*}{$\begin{array}{l}\text { Frekuensi bekerja bertatap muka } \\
\text { langsung dengan sasaran penyuluhan } \\
\text { kelompok pada masa pandemi COVID- } \\
19\end{array}$} & 1 kali seminggu & 46 & 32,86 \\
\hline & 2 kali seminggu & 37 & 26,43 \\
\hline & 3 kali seminggu & 33 & 23,57 \\
\hline & 4 kali seminggu & 14 & 10,00 \\
\hline & 5 kali seminggu & 3 & 2,14 \\
\hline & $\begin{array}{l}\text { Lebih dari } 5 \text { kali } \\
\text { seminggu }\end{array}$ & 7 & 5,00 \\
\hline
\end{tabular}

\section{HASIL DAN PEMBAHASAN}

Hasil

Hasil penelitian untuk mengkaji karakteristik kondisi dan faktor-faktor yang mempengaruhi tingkat mobilitas penyuluh perikanan pada masa pandemi COVID-19 dapat dilihat pada Tabel 1. Tingkat pemanfaatan teknologi informasi dan komunikasi oleh penyuluh perikanan dalam melaksanakan penyuluhan perikanan dapat dilihat pada Tabel 2. Hasil penelitian menggambarkan bahwa penerapan protokol kesehatan dan kondisi yang dialami Penyuluh Perikanan pada masa Pandemi COVID-19 ini dapat dilihat pada Tabel 3. 
Tabel 2. Pemanfaatan Teknologi Informasi dan Komunikasi oleh Penyuluh Perikanan dalam Mendukung Kegiatan Penyuluhan

\begin{tabular}{|c|c|c|c|}
\hline \multirow[b]{2}{*}{ Parameter } & \multirow[b]{2}{*}{ Kategori } & \multicolumn{2}{|c|}{ Responden } \\
\hline & & Jumlah & $\begin{array}{c}\text { Persentase } \\
(\%)\end{array}$ \\
\hline $\begin{array}{l}\text { Responden yang sudah mempunyai } \\
\text { atau membuat grup Whatsapp untuk }\end{array}$ & Belum & 53 & 37,86 \\
\hline $\begin{array}{l}\text { masing-masing kelompok perikanan } \\
\text { binaan }\end{array}$ & Sudah & 87 & 62,14 \\
\hline Frekuensi penggunaan fitur panggilan & Sering & 82 & 58,57 \\
\hline seluler atau pesan singkat atau chat & Kadang-Kadang & 52 & 37,14 \\
\hline $\begin{array}{l}\text { Whatsapp atau Voice Call Whatsapp } \\
\text { atau Video Call Whatsapp ke sasaran }\end{array}$ & Jarang & 5 & 3,57 \\
\hline $\begin{array}{l}\text { penyuluhan pada masa pandemi } \\
\text { COVID-19 }\end{array}$ & Tidak Pernah & 1 & 0,71 \\
\hline Responden yang paham dan biasa & Sangat paham & 23 & 16,43 \\
\hline menggunakan formulir daring, seperti & Paham & 87 & 62,14 \\
\hline Google Form, Zoho Form dan & Kurang paham & 26 & 18,57 \\
\hline sejenisnya. & Tidak paham & 4 & 2,86 \\
\hline $\begin{array}{l}\text { Pendapat tentang kemampuan dan } \\
\text { kemungkinan pertemuan kelompok }\end{array}$ & Bisa dan mungkin & 82 & 58,57 \\
\hline $\begin{array}{l}\text { dilakukan secara daring melalui Zoom, } \\
\text { Google Meet dan sejenisnya }\end{array}$ & Tidak bisa dan tidak mungkin & 58 & 41,43 \\
\hline $\begin{array}{l}\text { Pendapat tentang kemampuan dan } \\
\text { kemungkinan penyampaian materi }\end{array}$ & Bisa dan mungkin & 108 & 77,14 \\
\hline $\begin{array}{l}\text { penyuluhan dilakukan secara daring } \\
\text { melalui rekaman video internal, } \\
\text { Youtube, Podcast dan sejenisnya }\end{array}$ & Tidak bisa dan tidak mungkin & 32 & 22,86 \\
\hline Frekuensi membagikan file materi & Sering & 33 & 23,57 \\
\hline berupa PDF leaflet atau folder atau & Kadang-Kadang & 70 & 50,00 \\
\hline $\begin{array}{l}\text { power point atau lainnya kepada } \\
\text { sasaran penyuluhan melalui saluran }\end{array}$ & Jarang & 29 & 20,71 \\
\hline $\begin{array}{l}\text { komunikasi, seperti Whatsapp dan lain- } \\
\text { lain }\end{array}$ & Tidak Pernah & 8 & 5,71 \\
\hline
\end{tabular}

Hasil penelitian terkait pendapat penyuluh perikanan terhadap penerapan alternatif kebijakan yang dapat mendukung pelaksanaan penyuluhan perikanan selama pandemi COVID-19 dapat dilihat pada Tabel 4.

\section{Pembahasan}

Keadaan perkembangan permasalahan COVID- 19 terbaru di tiap-tiap wilayah berbeda-beda serta senantiasa berubah-ubah secara dinamis sepanjang waktu. Walaupun pada saat ini suatu daerah tidak atau belum berstatus Zona
Merah dan penerapan Pemberlakuan Pembatasan Kegiatan Masyarakat (PPKM) Darurat, maka tidak menutup kemungkinan rasa kewaspadaan dan rasa kekhawatiran yang ada di masyarakat untuk kontak fisik dengan orang lain yang datang jauh-jauh dan berkeliling di banyak daerah lainnya serta untuk berkumpul secara massal. Pelaksanaan penyuluhan perikanan dengan metode dan teknik kebiasaan lama yang bersifat konvensional, tatap muka, kontak fisik dan laporan-laporan berbasis 
Tabel 3. Penerapan Protokol Kesehatan dan Kondisi yang Dialami Penyuluh Perikanan pada Masa Pandemi COVID-19

\begin{tabular}{llcc}
\hline \multicolumn{1}{c}{ Parameter } & \multicolumn{1}{c}{ Kategori } & \multicolumn{2}{c}{ Responden } \\
\cline { 2 - 4 } & & Jumlah & $\begin{array}{c}\text { Persentase } \\
\text { (\%) }\end{array}$ \\
\hline & & Selalu & 90,00 \\
Frekuensi penggunaan masker ketika bekerja & Kadang-kadang & 12 & 8,57 \\
pada masa pandemi COVID-19 & Jarang & 2 & 1,43 \\
& Tidak Pernah & 0 & 0,00 \\
\hline & Selalu & 98 & 70,00 \\
Frekuensi penggunaan hand sanitizer ketika & Kadang-kadang & 30 & 21,43 \\
bekerja pada masa pandemi COVID-19 & Jarang & 8 & 5,71 \\
& Tidak Pernah & 4 & 2,86 \\
\hline $\begin{array}{l}\text { Responden yang pernah mengalami gejala- } \\
\text { gejala mirip yang dialami pasien terkonfirmasi } \\
\text { COVID-19, seperti batuk disertai demam, }\end{array}$ & Ya, pernah & 36 & 25,71 \\
$\begin{array}{l}\text { sesak napas, atau gejala sekadar hilang } \\
\text { indera penciuman dan indera pengecap pada } \\
\text { masa pandemi COVID-19 }\end{array}$ & Belum pernah & & \\
\hline $\begin{array}{l}\text { Responden yang pernah melakukan rapid test } \\
\text { swab antigen dan/atau PCR dengan hasil }\end{array}$ & Ya, pernah & 104 & 74,29 \\
reaktif / positif & Belum pernah & & \\
\hline
\end{tabular}

Tabel 4. Pendapat Responden terhadap Alternatif Kebijakan dalam Mendukung Kegiatan Penyuluhan selama Pandemi COVID-19

\begin{tabular}{llcc}
\hline \multicolumn{1}{c}{ Parameter } & \multicolumn{1}{c}{ Kategori } & \multicolumn{2}{c}{ Responden } \\
\cline { 3 - 4 } & & Jumlah & $\begin{array}{c}\text { Persentase } \\
\text { (\%) }\end{array}$ \\
\hline Pendapat responden jika pelaksanaan & Sangat setuju & 32 & 22,86 \\
penyuluhan perikanan pada masa pandemi & Setuju & 54 & 38,57 \\
COVID-19 ini dimasukkan ke dalam peraturan & Netral & 35 & 25,00 \\
atau keputusan Kepala BRSDM KP tentang & Tidak setuju & 17 & 12,14 \\
pedoman kerja darurat sehingga pelaksanaannya & Sangat tidak setuju & 2 & 1,43 \\
diwajibkan full daring tanpa tatap muka dan tanpa & & & \\
berkumpul secara fisik demi kesehatan penyuluh & & & \\
dan para pelaku utama perikanan, tetapi tetap & & & 18 \\
diakui sebagai barang bukti pengajuan DUPAK & & 26 & 18,57 \\
\hline Pendapat responden jika Biaya Operasional & Sangat setuju & 25,00 \\
Penyuluh (BOP) diberikan dalam bentuk paket & Setuju & 35 & 22,86 \\
berlangganan operator seluler pascabayar, seperti & Netral & 32 & 20,71 \\
Telkomsel HALO, XL Prioritas, Indosat & Kurang setuju & 29 & \\
Pascabayar dan sejenisnya. Paket yang berisi & Tidak setuju & & \\
kuota panggilan seluler, kuota Internet dan kuota & & & \\
SMS & & & \\
\hline
\end{tabular}

kertas manual akan terhambat pelaksanaannya pada masa pandemi ini.

Penyuluh perikanan masih bekerja dalam mengawal dan menyosialisasikan program-program Kementerian Kelautan dan Perikanan secara langsung kepada masyarakat, di tengah kondisi pandemi
COVID-19 yang melanda Indonesia dan negara-negara lainnya, dengan berbagai strategi, metode dan teknik penyuluhan yang dilakukan penyuluh perikanan (Choeronawati dan Rochman 2021). Berdasarkan data penelitian, sebagian 
besar penyuluh perikanan harus menempuh perjalanan sekurang-kurangnya 30 kilometer baik menggunakan kendaraan pribadi, kendaraan umum maupun kombinasi kendaraan pribadi dan kendaraan umum. Penggunaan kendaraan umum tentunya lebih berisiko lebih tinggi terpapar COVID-19 dibandingkan menggunakan kendaraan pribadi. Upaya yang dapat dilakukan adalah menghindari penggunaan kendaraan umum. Jika terpaksa menggunakan kendaraan umum, maka protokol kesehatan yang dilakukan selama melakukan perjalanan harus lebih disiplin dan lebih ketat, seperti memakai masker dengan benar, bahkan menggunakan pelindung wajah (face shield) akan lebih baik, tidak berbicara kepada siapa pun dan melalui media apa pun, menjaga jarak dengan penumpang lain, meminimalisir menyentuh benda dan permukaan, selalu menjaga kebersihan tangan, membawa bekal makan siang dari rumah, menghindari menyentuh mulut, mata dan hidung dengan tangan, serta menggunakan jaket atau baju berlengan panjang dan penutup kepala (Shen et al. 2020).

Hasil penelitian menggambarkan bahwa sebagian besar penyuluh perikanan berada satu kabupaten/kota yang sama dengan tempat tugas, akan tetapi ada juga sebagian kecil yang bekerja lintas kabupaten/kota bahkan lintas provinsi, sehingga mobilitas penyuluh perikanan tidak dapat dihindarkan ketika berangkat bekerja harus dilakukan pada masa pandemi COVID-19. Pemetaan kebutuhan penyuluh perikanan di masing-masing daerah dan pemerataan distribusi penyuluh perikanan diperlukan untuk menjawab persoalan ini, sehingga terjadi kesinambungan antara mendekatkan jarak, mengurangi mobilitas, mengoptimalkan kinerja serta pemenuhan kebutuhan dan pemerataan penyuluh perikanan di suatu daerah.

Hasil penelitian menunjukkan bahwa sebagian besar responden selalu memakai masker dan sebagian kecil yang kadang-kadang tidak memakai masker. Perihal penggunaan hand sanitizer, sebagian besar selalu menyediakan dan menggunakannya, akan tetapi masih ada juga penyuluh yang kadang-kadang, jarang bahkan ada yang tidak pernah menyediakan dan menggunakan hand sanitizer. Penggunaan masker dan hand sanitizer sudah menjadi barang wajib dan kebiasaan baru penyuluh perikanan dalam bekerja di lapangan.

Data penelitian menggambarkan bahwa frekuensi kunjungan perorangan (anjangsana) penyuluh perikanan ke sasaran penyuluhan pada masa pandemi ini masih tetap dilakukan, minimal tiga kali seminggu, dan frekuensi pertemuan kelompok perikanan masih juga 
dilakukan minimal satu kali seminggu. Hal ini menjadi potensi terpapar dan penyebaran infeksi COVID-19 masih mungkin bisa terjadi jika protokol kesehatan tidak dilakukan dengan benar, baik oleh penyuluh perikanan maupun sasaran penyuluhan dan masyarakat lainnya pada umumnya.

Berdasarkan data penelitian, tergambar bahwa penyuluh perikanan yang pernah mengalami gejala-gejala yang biasa dialami oleh pasien terkonfirmasi positif COVID-19 sebanyak 25,71 persen, dan penyuluh perikanan yang pernah mendapatkan hasil reaktif atau positif melalui rapid test swab antigen atau test PCR (polymerase chain reaction) sebanyak 24,29 persen. Hal ini menunjukkan bahwa resiko terpapar infeksi COVID-19 masih bisa terjadi kepada penyuluh perikanan dengan berbagai mobilitas dan interaksi yang dilakukan selama bertugas di lapangan. Hal ini senada dengan yang diungkapkan oleh World Health Organization (2020) bahwa salah satu langkah penangkalan terpaparnya COVID-19 di area kerja ialah membatalkan ataupun menunda perjalanan non-esensial ke tempattempat di mana terjadi penularan COVID-19, membagikan pembersih tangan (hand sanitizer) kepada para pekerja yang wajib melaksanakan perjalanan serta menganjurkan para pekerja untuk mematuhi instruksi dari badan-badan pemerintah di tempat tujuan perjalanan.

Siti Aminah dalam Praherdhiono et al. (2020) menerangkan bahwa setelah terjadi pandemi COVID-19, akan terjadi pemikiran bahwa banyak hal yang harus dipersiapkan. Pemikiran yang terjadi adalah banyak orang yang menginginkan perlunya antisipasi terhadap pembelajaran yang selalu berubah dalam rangka penyesuaian setiap kondisi. Salah satu indikasi keinginan masyarakat adalah kegiatan yang rutin dan kegiatan yang yang memiliki pola yang sama, baik pada masa pandemi COVID19 maupun pada masa yang akan datang, sehingga pelayanan akan tetap jalan baik waktu terjadi pandemi, maupun kondisi pada masa yang akan datang, ini disebut mesin otomasi. Kegiatan penyuluhan harus peka terhadap perkembangan teknologi komunikasi dan teknologi informasi. Era digital menjadi suatu keniscayaan, sehingga diperlukan perubahan paradigma penyuluhan pada masa mendatang. Pendekatan Latihan dan Kunjungan (LAKU) yang dulu merupakan pendekatan yang dinilai paling efektif, tampaknya saat ini harus ditinjau kembali penerapannya (Taryoto 2019).

Tingkat penggunaan teknologi informasi dan komunikasi di sasaran penyuluhan pelaku utama perikanan, relatif sudah mengikuti perkembangan 
zaman. Ratnadila, Taryoto, dan Leilani (2019) menyatakan bahwa setelah kegiatan penyuluhan perikanan, sasaran penyuluhan mendapatkan banyak manfaat dari adanya teknologi informasi dan relatif banyak yang menerapkannya dalam kegiatan usaha perikanan yang mereka lakukan. Sebagian besar sasaran penyuluhan sudah menggunakan Smartphone dan aplikasi pesan instan, seperti whatsapp, facebook messenger dan aplikasi sejenisnya. Jikalau sasaran utama tidak atau belum menggunakan aplikasi pesan instan tersebut, maka sebenarnya sasaran tambahan seperti istri dan anak-anak yang bersangkutan sebagian besar sudah menggunakan smartphone dan akrab dengan aplikasi-aplikasi pesan instan dan formulir daring tersebut. Senada dengan hasil penelitian Nurhayati (2019) yang menyimpulkan bahwa para pengguna aplikasi whatsapp menilai aplikasi ini cukup dibutuhkan bagi pemilik smartphone. Hampir setiap orang sudah memiliki whatsapp baik dari kalangan remaja, ibu-ibu, dan bapakbapak. Pesan dakwah yang disampaikan para pengguna media sosial whatsapp. Para responden menyatakan pesan yang berkaitan tentang agama dapat meningkatkan pengetahuan dan keagamaan. Karena aplikasi ini tidak membatasi sebanyak apa pun teks yang akan dikirim atau diterima dan bisa digunakan kapan dan di mana pun.

Teknologi informasi serta komunikasi bisa dimanfaatkan guna tingkatkan bidang pertanian ataupun memberdayakan warga khususnya para petani di pedesaan. Pemanfaatan teknologi informasi serta komunikasi untuk warga pedesaan salah satunya merupakan selaku media pendidikan untuk berbagai bidang, misalnya dalam membangun akses informasi ataupun multimedia bagi warga pedesaan (Ramadhianto et al., 2011 dalam Praditya 2016). Semakin sering penyuluh menggunakan internet dalam menyusun laporan, pembuatan modul, penyusunan programa serta mendesain tata cara penyuluhan hingga kinerja penyuluh dalam persiapan aktivitas penyuluhan pertanian, penerapan aktivitas penyuluhan pertanian serta penilaian penyuluhan pertanian akan terus menjadi baik (Purwatiningsih, Fatchiya, dan Mulyandari 2018).

Pemanfaatan grup Whatsapp yang beranggotakan para ketua kelompok perikanan binaan penyuluh perikanan dapat lebih dioptimalkan pada masa pandemi COVID-19. Selain itu, grup-grup Whatsapp untuk masing-masing kelompok perikanan binaan penyuluh perikanan juga dapat dimaksimalkan pemanfaatannya. Jika diperlukan rapat koordinasi antara penyuluh perikanan dan para 
pengurus kelompok binaan, ketua, sekretaris dan bendahara, maka dapat dilakukan melalui Whatsapp dengan fitur Video Call Grup yang hingga saat ini sudah mendukung hingga 8 peserta sekaligus. Jika diperlukan penyebaran materi dalam berbagai bentuk publikasi dan penyampaian pesan suara dapat dilakukan melalui grup Whatsapp masing-masing kelompok perikanan binaan yang sudah dibuat.

Berdasarkan data penelitian, sebanyak 62,14 persen penyuluh perikanan sudah membuat atau mempunyai Whatsapp Grup untuk masing-masing kelompok perikanan binaan. Penyuluh perikanan sebanyak 58,57 persen sudah sering menggunakan fitur panggilan seluler atau pesan singkat atau chat whatsapp atau voice call whatsapp atau video call whatsapp kepada sasaran penyuluhan pada masa pandemi COVID19 ini. Penyuluh perikanan sebanyak 23,57 persen sudah sering membagikan file materi berupa file PDF (portable document format) materi penyuluhan berupa leaflet atau folder atau power point atau lainnya kepada sasaran penyuluhan melalui saluran komunikasi, seperti whatsapp dan media sosial lainnya.

Sedangkan untuk tetap menyelaraskan kegiatan kunjungan, penyuluhan dan pendampingan tersebut dengan penilaian kinerja serta upaya pengembangan karier Penyuluh Perikanan, maka laporan-laporan berbasis teknologi berbentuk formulir daring juga sangat diperlukan serta tetap dapat diselaraskan dengan mekanisme pengumpulan bukti non-fisik untuk usulan DUPAK (Daftar Usulan Penetapan Angka Kredit) Penyuluh Perikanan.

Data penelitian menyatakan bahwa sebanyak 78,57 persen penyuluh perikanan sangat paham dan paham dalam menggunakan formulir daring, seperti Google Form, Zoho Form atau sejenisnya. Formulir daring dibuat dengan pertimbangan pemilihan jenis produk teknologi informasi dan komunikasi yang memberikan dukungan fitur pembubuhan tanda tangan pada formulir tersebut dan relatif mudah digunakan oleh sasaran penyuluhan. Hingga saat ini, Zoho Forms yang dapat dimanfaatkan untuk pelaksanaan dalam rangka pencapaian maksud dan tujuan tersebut. Purwarupa templat formulir daring laporan kunjungan penyuluhan virtual oleh penyuluh perikanan kepada sasaran penyuluhan dapat dilihat di https://s.id/formkunjunganvirtual dan https://s.id/formkunjungankelompokvirtu al.

Data penelitian menunjukkan bahwa sebanyak 77,14 persen penyuluh perikanan berkeyakinan bahwa bisa dan 
mungkin jika penyampaian materi penyuluhan dilakukan secara daring melalui rekaman video maupun rekaman suara yang dipublikasikan melalui layanan berbagi video dan audio, seperti youtube, podcast dan media sejenisnya. Selain itu, sebanyak 58,57 persen penyuluh perikanan berkeyakinan bahwa bisa dan mungkin bahwa pertemuan kelompok dapat dilakukan secara daring melalui layanan video conference, seperti Zoom Meeting, Google Meet, Microsoft Team atau aplikasi sejenisnya. Hal ini akan cepat terwujud jika dilakukan persiapan, kursus singkat kepada salah satu pengurus atau anggota kelompok perikanan binaan serta dukungan saranaprasarana yang memadai, termasuk insentif atau bantuan kuota internet bagi penyuluh perikanan dan/atau kepada kelompok perikanan binaan.

Mengakomodir para sasaran penyuluhan yang sama sekali tidak ada akses jaringan internet atau kualitas jaringan internet yang kurang mumpuni dan berkualitas buruk maupun tidak ada seorang pun yang tinggal satu rumah dengan sasaran penyuluhan yang sudah menggunakan Smartphone, maka dapat menggunakan fitur teknologi informasi dan komunikasi berbasis SMS (Short Message Service) yang dikirim secara massal kepada sasaran penyuluhan tersebut atau disebut dengan SMS Gateway. SMS Gateway merupakan sebuah platform yang menyediakan mekanisme untuk mengirim dan menerima sebuah pesan singkat berupa teks melalui perangkat komunikasi berupa telepon genggam (Mauludin 2015). Pada penggunaan fitur ini, biasanya ada pembatasan-pembatasan tertentu, baik dari segi jumlah maupun waktu pengirimannya dari pihak operator seluler dalam rangka meminimalisir penyalahgunaan SMS (Short Message
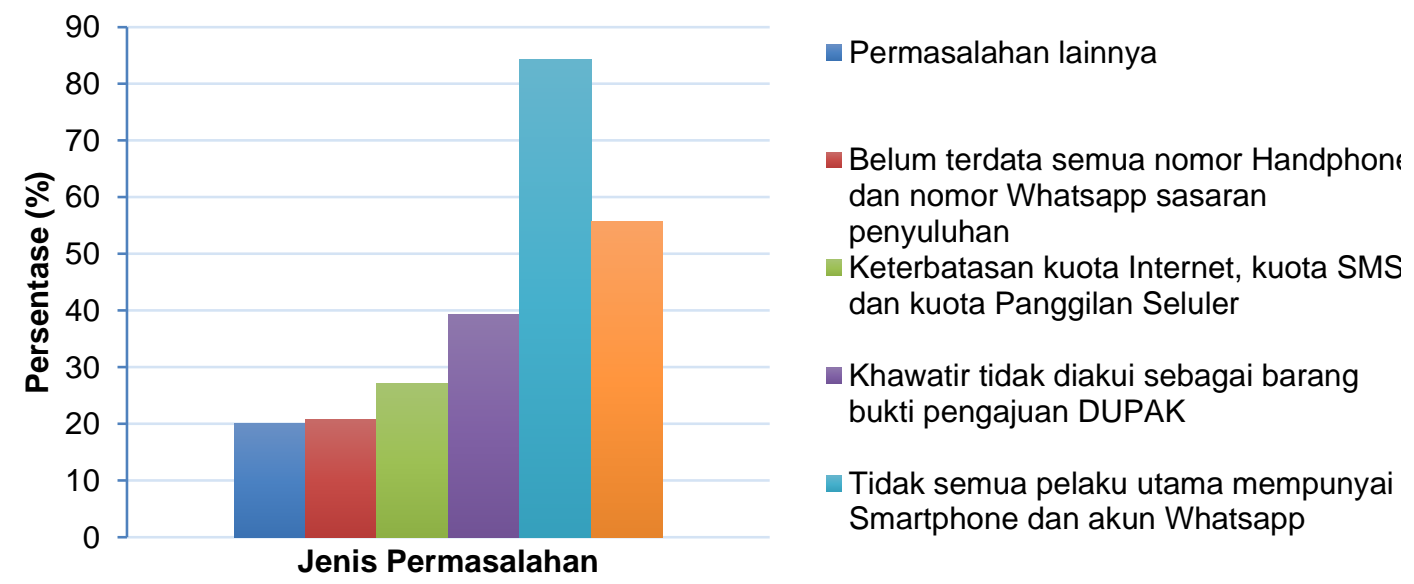

Gambar 1. Grafik Kendala yang Dihadapi Penyuluh Perikanan dalam Menerapkan Penyuluhan Perikanan secara Daring pada Masa Pandemi COVID-19 
Service) untuk pesan sampah (spam) dan kegiatan-kegiatan ilegal secara hukum lainnya. Permasalahan yang masih menjadi beban para penyuluh perikanan pemanfaatan teknologi informasi dan komunikasi terkini, dalam rangka pelaksanaan penyuluhan perikanan secara daring pada masa pandemi COVID-19 ini, berdasarkan data hasil penelitian dapat dilihat pada Gambar 1.

Data penelitian dapat disimpulkan bahwa terdapat tiga permasalahan yang mendominasi yaitu di antaranya 1) tidak semua pelaku utama mempunyai smartphone dan akun Whatsapp sebanyak 84 persen; 2) Sinyal internet kurang memadai kecepatan dan kestabilannya sebanyak 56 persen; dan 3) khawatir tidak diakui sebagai barang bukti pengajuan DUPAK (Daftar Usulan Penetapan Angka Kredit) sebanyak 39 persen. Adapun beberapa alternatif solusi dari tiga permasalahan dominan tersebut dapat dilihat pada Tabel 5.

Berdasarkan data penelitian, sebanyak 61,43 persen penyuluh perikanan berpendapat sangat setuju dan setuju jika pelaksanaan penyuluhan perikanan pada masa Pandemi COVID-19 ini dirumuskan ke dalam peraturan atau keputusan kepala Badan Riset dan Sumber Daya Manusia Kelautan dan Perikanan (BPSDMKP) tentang pedoman kerja darurat bagi penyuluh perikanan pada masa pandemi COVID-19 sehingga pelaksanaannya diwajibkan secara daring (full online) tanpa tatap muka dan tanpa berkumpul secara fisik demi menjaga kesehatan penyuluh perikanan dan kesehatan para pelaku utama perikanan, tetapi tetap diakui sebagai barang bukti pengajuan DUPAK (Daftar Usulan Penetapan Angka Kredit) jabatan fungsional penyuluh perikanan.

Berdasarkan data penelitian, sebanyak 31,43 persen penyuluh perikanan berpendapat sangat setuju dan setuju jika Biaya Operasional Penyuluh (BOP) diberikan dalam bentuk paket berlangganan yang berisi kuota panggilan seluler, kuota Internet dan kuota SMS operator pascabayar, seperti Telkomsel HALO, XL Prioritas, Indosat Freedom Postpaid dan produk sejenisnya. Hal ini selaras dan tidak bertentangan dengan amanat Undang-undang Nomor 16 Tahun 2006 tentang Sistem Penyuluhan Pertanian, Perikanan dan Kehutanan; pasal 32 yang berbunyi "Untuk menyelenggarakan penyuluhan yang efektif dan efisien diperlukan tersedianya pembiayaan yang memadai untuk memenuhi biaya penyuluhan. Sumber pembiayaan untuk penyuluhan disediakan melalui APBN, APBD baik provinsi maupun kabupaten/kota, baik secara sektoral maupun lintas sektoral, maupun sumbersumber lain yang sah dan tidak mengikat. Pembiayaan penyuluhan yang berkaitan dengan tunjangan jabatan 
Tabel 5. Alternatif Solusi Pemecahan Masalah yang Dihadapi Penyuluh Perikanan

No. Jenis Permasalahan

Tidak semua pelaku utama

1. mempunyai smartphone dan akun Whatsapp

2. Sinyal internet kurang memadai kecepatan dan kestabilannya
Alternatif Solusi Pemecahan Masalah

a. Menggunakan smartphone yang dimiliki oleh istri atau anak pelaku utama yang masih tinggal serumah;

b. Memaksimalkan fungsi komunikasi panggilan seluler dan pengiriman SMS secara massal.

a. Mencari lokasi tertentu yang terindikasi mempunyai sinyal yang stabil dengan kecepatan yang mumpuni.

b. Menggunakan layanan operator seluler lainnya yang sinyalnya paling stabil dan kecepatannya mumpuni di daerah atau wilayah masing-masing

a. Penerapan kebijakan internal dari Tim Penilai DUPAK masing-masing unit kerja

Khawatir tidak diakui sebagai

3. barang bukti pengajuan DUPAK

b. Menerbitkan peraturan atau keputusan Kepala BRSDM KP tentang pedoman kerja darurat penyuluh perikanan pada masa pandemi COVID-19 guna mengakomodir jejak digital sebagai barang bukti pengajuan DUPAK. fungsional dan profesi, biaya operasional penyuluh PNS, serta sarana dan prasarana bersumber dari APBN." Penyediaan kuota internet sangat relevan untuk mendukung penyelenggaraan penyuluhan dalam masa pandemi saat ini.

\section{SIMPULAN DAN SARAN}

Penyuluh perikanan masih tetap beraktivitas menjalankan tugas pada masa pandemi dengan protokol kesehatan yang ketat, walaupun dengan intensitas yang relatif menurun sejak awal pandemi hingga sekarang. Karakteristik penyuluh perikanan dalam melaksanakan tugas masih bervariasi; ada sebagian yang masih bekerja dengan kebiasaan lama bertatap muka secara fisik; dan ada sebagian yang sudah menerapkan Work from Home (WFH). Data penelitian menunjukkan kondisi penyuluh yang pernah mengalami gejala mirip pasien COVID-19 sebanyak 25,71 persen dan terkonfirmasi reaktif atau positif terpapar infeksi virus COVID-19 sebanyak 24,29 persen. Strategi dan metode penyuluhan perikanan dilakukan secara luring dan daring dengan protokol kesehatan yang ketat dan penggunaan beragam produk teknologi komunikasi. Namun demikian, masih ada beberapa hambatan baik internal maupun eksternal. 
Saran yang dapat menjadi pertimbangan adalah instansi pembina penyuluh adalah perlu segera menyusun peraturan perundang-undangan berupa Peraturan Kepala Badan Riset dan Sumber Daya Manusia Kelautan dan Perikanan tentang Pedoman Kerja Darurat Penyuluh Perikanan pada masa pandemi. Pedoman kerja darurat tersebut diharapkan dapat membantu mengurangi kendala yang dihadapi penyuluh, sasaran penyuluhan dan instansi pembina. Pedoman ini diharapkan berguna untuk melegalkan kegiatan penyuluhan secara daring dan virtual, sehingga sasaran penyuluhan dapat terlayani dengan baik dan penyuluh mendapat jaminan penghargaan berupa pengakuan jejak digital sebagai bukti pelaksanaan kegiatan dalam pengajuan DUPAK (Daftar Usulan Penetapan Angka Kredit).

\section{PERSANTUNAN}

Penulis mengucapkan terima kasih kepada Ibu Sukma Budi Prasetyati, S.Pi., M.Tr.Pi yang telah membantu dan memberikan arahan dalam penyusunan laporan penelitian ini. Penulis juga mengucapkan terima kasih kepada pihak-pihak terkait lainnya yang telah berkontribusi dalam penelitian ini. Penghargaan setinggi-tingginya disampaikan kepada 1) Sutrisno; 2) Yanuar Alamanda; 3) Udin Situmeang; 4) Iwayan Sutama; 5) Sugimin; 6) Yaya Mulyadi; 7)
Otan Darul Mutaqin, dan 8) Margareta Ratih Manjari yang telah gugur dalam menjalankan tugas pada masa pandemi COVID-19 ini.

\section{DAFTAR PUSTAKA}

Choeronawati, Anggih Isti, dan Nur Rochman. 2021. "Strategi Penyuluhan Kelautan dan Perikanan Dalam Masa Pandemi Covid-19 di Kecamatan Purworejo." Abdi Insani 7(3):24755.

Mardikanto, Totok. 2011. Metoda penelitian dan evaluasi pemberdayaan masyarakat: untuk akademisi, praktisi dam peminat pemberdayaan masyarakat. Surakarta (ID): Program Pascasarjana UNS.

Mauludin, Mochamad Subchan. 2015. "SMS Gateway sebagai Media Publikasi Murah." Media Elektrika 8(2).

Nurhayati. 2019. "Efektifitas Penggunaan Media Sosial (Whatsapp) dalam Penyampaian Pesan Dakwah terhadap Kalangan Remaja di Desa Seritanjung [Skripsi]." Universitas Muhammadiyah Palembang.

Peraturan Menteri Kelautan dan Perikanan Nomor 38 tahun. 2013. tentang Kebijakan dan Strategi Penyuluhan Perikanan. 
Praditya, Didit. 2016. "Pemberdayaan Petani Oleh Komunitas Teknologi Informasi dan Komunikasi (TIK)." Jurnal Penelitian Komunikasi 19(1):41-54.

Praherdhiono, Henry, Eka Pramono Adi, Yulias Prihatmoko, Nunung Nindigraha, Yerry Soepriyanto, Henny Indreswari, dan Herlina Ike Oktaviani. 2020. Implementasi Pembelajaran Di Era Dan Pasca Pandemi Covid-19. Malang (ID): Seribu Bintang.

Prayoga, Kadhung. 2017. "Pemanfaatan Media Sosial dalam Penyuluhan Pertanian dan Perikanan di Indonesia." Agriekonomika 6(1).

Purwatiningsih, Nanik Anggoro, Anna Fatchiya, dan Retno Sri Hartati Mulyandari. 2018. "Pemanfaatan Internet dalam Meningkatkan Kinerja Penyuluh Pertanian di Kabupaten Cianjur." Jurnal Penyuluhan 14(1).

Ratnadila, Nila Sylvi, Andin H. Taryoto, dan Ani Leilani. 2019. "Pemanfaatan Media Teknologi Informasi dalam Penyelenggaraan Penyuluhan Perikanan (Kasus Penyuluh Perikanan Kabupaten Tabanan Provinsi Bali)." Jurnal Penyuluhan Perikanan dan Kelautan 13(2):189-204.
Rustanto, Bambang. 2015. Penelitian Kualitatif Pekerjaan Sosial. Bandung (ID): Remaja Rosdakarya.

Shen, Jin, Hongyang Duan, Baoying Zhang, Jiaqi Wang, John S. Ji, Jiao Wang, Lijun Pan, Xianliang Wang, Kangfeng Zhao, Bo Ying, Song Tang, Jian Zhang, Chen Liang, Huihui Sun, Yuebin Lv, Yan Li, Tao Li, Li Li, Hang Liu, Liubo Zhang, Lin Wang, dan Xiaoming Shi. 2020. "Prevention and control of COVID19 in public transportation: Experience from China." Environmental Pollution 266:115291.

Suadnya, I. Wayan, Agus Purbathin Hadi, dan Eka Putri Paramita. 2021. "Strategi Komunikasi dan Kinerja Penyuluh Pertanian Dimasa Pandemi Covid-19 di Kabupaten Lombok Tengah." in Prosiding Saintek. Mataram (ID): Universitas Mataram.

Sutarna, Nana, Arrofa Acesta, Nika Cahyati, Sendi Fauzi Giwangsa, Dedi Iskandar, dan Harmawati Harmawati. 2021. "Dampak Pembelajaran Daring terhadap Siswa usia 5-8 tahun." Jurnal Obsesi: Jurnal Pendidikan Anak Usia Dini 6(1):288-97. 
Taryoto, Andin H. 2019. "Reformasi Kegiatan Penyuluhan: Perlukah ....? Pendekatan Pembangunan dan Pengelolaan Sumber Daya Pertanian." Diambil (https://www.academia.edu/40474 789/PENYULUHAN_MASA_DEPA N-MAKALAH_AHT).

Undang-undang Nomor 16 Tahun. 2006. tentang Sistem Penyuluhan Pertanian, Perikanan, dan Kehutanan.

Wibowo, Agung. 2020. "Masalah dan Tantangan Penyuluhan Pertanian di Era Pandemi Covid-19: Review." in Prosiding Seminar Nasional Fakultas Pertanian UNS. Surakarta (ID): Fakultas Pertanian Universitas Sebelas Maret.
World Health Organization. 2020. "Pertimbangan langkah-langkah kesehatan masyarakat dan sosial di tempat kerja dalam konteks COVID-19."

Diambil (https://www.who.int/docs/defaultsource/searo/indonesia/covid19/w ho---pertimbangan-langkahlangkah-kesehatan-masyarakatdan-sosial-di-tempat-kerja-dalamkonteks-covid19.pdf?sfvrsn=b8a19986_2). 